\title{
Research on the Problems about Teaching Management of University Credit System Problems and Countermeasures
}

\author{
Wei Xiong ${ }^{1}$ \\ ${ }^{1}$ Jiangxi College of Foreign Studies, Nanchang, Jiangxi, 330099 \\ 59624917@163.com
}

Keywords: University Credit System; Problems and Countermeasures; Education

\begin{abstract}
With the social, economic development and economic globalization, China has accelerated the pace with the world. With the changes in the 1990s economic system, the education system has been gradually deepened, Chinese universities launched a new round of upsurge credit system Reform. On the beginning of the century, as the main feature of the credit Teaching Management system, it is a nationwide system at Colleges and Universities. Up to now, most of China's colleges and universities are in the implementation of different forms of credit.
\end{abstract}

\section{Introduction}

Credit is a kind of elective system as the basis, credit for the units of measurement, teaching management system to measure the elasticity of student learning process. Different times, different people have different interpretations. "International Encyclopedia of Higher Education" will be interpreted as a credit "is a measure of a teaching process (usually a course) to complete the degree requirements for contribution (the role, status) of a management method." "Encyclopedia of China • Education "will be interpreted as a credit" is a teaching management system of colleges and universities. It credits as students calculate the amount of the unit. "" Education Management Dictionary "will be summed up as" students to calculate the amount of credit as a unit in order to obtain the minimum necessary standards of teaching as a graduation credit management system. " "Higher Dictionary" is defined as: "a teaching management system, mainly used in colleges and universities, in order to learn to calculate the amount of credit units." Based on the above point of view, the basic meaning is clear Credit: 1 to credit as the unit of measurement. 2, students taking any course results qualified, you can get the course prescribed learning scores. 3 , the value of each credit is equal to 1 different courses and different courses credits can be added to obtain the total credits. 4, students will obtain a predetermined total credits will be allowed to graduate and there is no limit on the length of schooling in principle.

\section{The Status of University Credit System}

Through the survey found that, in closed questions "alternative curriculum provided by the school can meet your needs Course" in 26 percent of the students said, "alternative subjects too," students can not meet the enrollment requirements. 22\% of the students chose "compulsory proportion too big", resulting in not interested in some of the electives. In the "Do you think the school teaching programs recommended credit allocation is reasonable", there are $42.4 \%$ of students think too much credit required course share instructional program in their schools, so that students after the completion of the school provides teaching programs, there is no How much time and energy to other elective courses, so that can not be implemented independent elective. While the closed questions in Question 2 have alternative subjects and teaching programs involving the allocation of credits, but in the end the open-ended question, "What do you think the biggest problem of teaching management schools currently exist?", 55.8 percent Students answer is curriculum, curriculum unreasonable. $39.3 \%$ of teachers feel that "currently the biggest problem in teaching management" is the problem of curriculum, curriculum arrangements. Which involves arranging time is unreasonable, compulsory elective time conflict, busy uneven week, noon break 
time is too short, too many platforms lesson practice class curriculum too, through knowledge training, and other courses.

Found from the survey on the "you know the school's enrollment requirements and operating procedures do", $24.8 \%$ of the students chose "need guidance", 13.4 percent of select "do not know." And on the "what do you think the biggest problem is the Course?" 16 percent of the students chose "do not know elective requirements and operating procedures." For elective basis, 39\% of students choose elective basis interest. $29 \%$ of the students on the basis of the knowledge structure Course. 18.7 percent of students according to their future career need Course. 7.6 percent of students according elective course difficulty. $1 \%$ of students in other things are as elective basis. Only 4.7 percent of the students can consider interests, knowledge structure, and future career needs. From a survey of teachers found that $41.9 \%$ of teachers think students choose courses unreasonable, need guidance. $1.0 \%$ of teachers think students choose courses very unreasonable, the need to strengthen guidance.

\section{The Countermeasures to University Credit System}

Development of management thinking can be traced back humanity's collective labor produced, but the formation of a system of management theory, but a hundred years of history. From the early 1900s to produce Taylor's scientific management theory, management theory through its own development process, from the jungle to the management process school administration, school systems, contingency approach, each theory on the development of Chinese management theory have had an impact. Today, management has gradually abandoned the traditional management of people see things but not the way, more and more attention to people's attention, more and more attention to human, respected people management. In China thousands of years of feudal society is hierarchical, officials and the public clear boundaries, even today, this influence is everywhere, all managers are generalized as "official", virtually stand in opposition to the managed object lack of empathy, resulting in policy or because of the lack of human care manager official standard thought or personal knowledge, training, personal effects, resulting in a lack of humanity in policy implementation. People management theory failed to implement.

The formation of the concept is not an overnight thing, but a concept, once formed, its impact can be eliminated more than short-term, China implemented a planned economy in decades, people in the depths of consciousness has been accustomed to relying on the government. While in 1998 promulgated the "People's Republic of China Higher Education Act" clearly states that "The State shall establish financial allocations to the main variety of other channels to raise funds, supplemented by higher education institutions," but due to the influence of traditional ideas, many colleges and universities have become accustomed to the planned economy system, the government produced a variety of colleges and universities to rely on inertia. To some extent still exists, "and so on, rely on, to" phenomenon, can not actively raise funds through other channels to compensate for the lack of funding for education, leading to lack of educational resources, can not meet the credit needs. Such as inadequate reserves outstanding teachers; classroom can not meet credit requirements of the Arrangement; when the elective computer is not enough time to focus and so on. In the fierce competition in order to obtain sustainable development, to solve the problems in the credit system reform, there must be a sense of self-development of colleges and universities, do everything possible to seek development opportunities.

Governance Theory from the Perspective of us to re-examine the relationship between government and universities, government and universities will no longer find a narrow government the power to control and university autonomy binary oppositions, but a "pluralistic one" relationship. That is the same kind of political system (ie adhere to the basic system of socialism), the governing body of higher education includes both university government also acknowledged as an important independent school, "one yuan", which is acknowledged by law schools universities become the subject. In this "integrated pluralistic," a new relationship between government and universities face many common issues and challenges, government departments must change their ideas, the implementation of the right to host the separation of power, authority, school rights. Government is 
organized by the University, the University enjoys ownership; University enjoys independent right school. Thus, the government, clearly define the roles between universities, government intervention in microeconomic affairs do not belong to the school of internal management, so that universities enjoy full autonomy in teaching, research, and other aspects of the use of funds, to become a legal entity of a true community-oriented school, Government's role will shift to higher macro-control, to solve those universities themselves can not solve but seriously restricted the operation and development of university external environmental problems.

Depending on how a managed object, take the appropriate incentives, is every manager should think about a university teacher is a special group, according to Maslow's hierarchy of needs theory of human needs from low to high is divided into five levels: physiological needs, security needs, love and belonging needs, esteem needs, self-actualization needs. It required only when the lower level after the human needs met only pursuit. But this need not comply levels rise progressively "full" or "no" rule. In real life people who under normal circumstances, they are part of every need is met, partially not met. Maslow also pointed out that: a high level of need, not only a wide range of content than the low level and increasingly difficult to achieve increases may meet increasingly reduced. University teachers and students are highly intelligent two groups, particularly eager to get respect and self-realization of their common, on the other hand, their psychological needs and there is a wealth of personality traits.

Management expert Peter Drucker pointed out: the organization effecting from everyone in the organization is able fullest play to their wisdom. Universities are the cradle of various cutting-edge knowledge of the target group is teaching management in all aspects of high-end talent, so managers need to have a higher education public management skills, and credit management and traditional management has a great school system different, compared to the academic year "unified teaching plan, a unified teaching materials, a unified graduation time" This is similar to "batch" of management, this personalized credit management, management of teaching staff put forward higher requirements in addition to the daily management, the management staff to do a lot of counseling work, how to guide students according to the intrinsic link between knowledge, taking into account their interests, hobbies and future job requirements, and reasonable arrangements for their own courses and learning progress, which In addition to the requirements of management personnel familiar with the various policies and regulations, but also must be familiar with the professional teaching plan, understand the intrinsic link between knowledge, knowledge structure. In addition, college students are a special group, they are smart, curious, receptive to new knowledge, but everyone has a distinct personality, the information received is not passive absorption, if not taken proper way to communicate, often backfire, so the teaching management staff must also have a certain knowledge of psychology, an understanding of the student's personality, and even to have been involved in social and professional development. Credit management is very complex, the traditional manual operation can not complete a large number of elective, have withdrawn, it all must use modern management tools, therefore, teaching management personnel with modern management concepts must grasp the scientific management knowledge, familiar concept to grasp office automation and network technology.

\section{Conclusion}

Any kind of system, improve not easy, Credit reform is a systematic project, is bound to be social and economic development, constraints related to national policies and other internal management system of colleges and universities, different countries, different regions different universities have different historical and cultural backgrounds and realistic conditions, in implementation of the credit system will encounter different problems, through complex surface phenomena, to find where the common, regular things, combined with the specific schools situation, timely adjustment, credit in order to gradually perfected. 


\section{References}

[1] Z.Y. Bao. The University Credit System Problems Existed in The Process of Research. Chinese Journal Net, 2003

[2] Y.S. Gao. Credit Development of American Universities Study. Chinese Journal Net, 2005

[3] Z.C. Gong. Palace Based Reconstruction Governance Theory of the Relationship Between Government and Universities. Sichuan Vocational and Technical College, 2005,15 (4)

[4] Geng Jian. Selection of Public Administration of Chinese Higher Education-On The Direction And Way For College Management System. Higher, 2005, 3. 